Caligrama, Belo Horizonte, v. 23, n. 3, p. 63-82, 2018

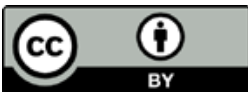

\title{
Prelúdio a um genocídio: memória, rumor e teor testemunhal na narrativa de Scholastique Mukasonga ${ }^{1}$
}

\section{Prelude to a Genocide: Memory, Rumor and Testimonial Content in the Narrative of Scholastique Mukasonga}

\author{
Adriana Cristina Aguiar Rodrigues \\ Universidade Federal do Amazonas (UFAM), Manaus, Amazonas / Brasil \\ Universidade Estadual de Campinas (Unicamp), Campinas, São Paulo / Brasil \\ adrianaguiarodrigues@gmail.com
}

Resumo: O artigo analisa o compromisso com a memória tutsi e o teor testemunhal presente na narrativa da escritora e sobrevivente ruandesa Scholastique Mukasonga. Na primeira seção, analisa-se o contexto de surgimento de uma literatura decorrente do genocídio, dando destaque ao trabalho (quase etnográfico) de inscrição da cultura tutsi e da memória das vítimas e sobreviventes empreendido por Mukasonga. Em seguida, passa-se a analisar como a autora constrói em sua narrativa o relato de teor testemunhal, ao mesmo tempo em que revisa, via literatura, os rumores e os discursos - nascidos no período colonial e mantidos durante a independência do país - que culminaram na catástrofe de 1994.

Palavras-chave: memória; rumor; teor testemunhal; Scholastique Mukasonga.

Abstract: This article analyzes the commitment to Tutsi memory and the testimonial content, which exists within the narrative of Rwandan writer and survivor Scholastique Mukasonga. In the first section, the context of a literature arising from the genocide is analyzed, highlighting the work (almost ethnographic) of the inscription of the Tutsi culture and the memory of the victims and survivors done by Mukasonga. Then it proceeds to analyze how the author constructs in her narrative the report of testimonial content, at the same time that it reviews, through literature, the rumors and discourses

\footnotetext{
${ }^{1}$ Pesquisa financiada pela CAPES, via Fundação de Amparo à Pesquisa do Estado do Amazonas (FAPEAM).
} 
- generated in the colonial period and maintained during the independence of the country - that culminated in the 1994 catastrophe.

Keywords: memory; rumor; witness content; Scholastique Mukasonga.

\section{1 "Écrire par devoir de mémoire": a literatura que nasce de escombros}

País de tradição oral, é possível organizar cronologicamente a produção literária ruandesa em dois períodos. Do antigo Reino de Ruanda pode-se falar de uma literatura oral das tradições da corte e das tradições populares, com a circulação de mitos, rituais, poesias, provérbios, canções e genealogias de reis que passavam de geração em geração - tarefa confiada a determinados grupos familiares, que garantiam a memorização e transmissão dos textos. Se as colonizações alemã e belga introduziram mudanças e impactos nessa tradição, os cem dias vividos entre abril e julho de 1994 acabaram atuando como um evento fundador de uma literatura ruandesa contemporânea: nascia, assim, uma escrita do caos e da dor. É verdade que essa literatura se constrói, ao menos inicialmente, não em kinyarwanda, mas pelas mãos de escritores de origem norte-americana e europeia, que se deslocaram para os locais onde haviam ocorrido os massacres e, em trabalho de investigação, lançaram, em língua inglesa e francesa, obras que se tornaram mais conhecidas no ocidente.

Só em um segundo momento passamos a ter acesso a publicações de autores africanos. Um exemplo decorrente de ações surgidas no continente é a operação "Rwanda: écrire par devoir de mémoire", idealizada em 1995 e colocada em prática em 1998 por Nocky Djedanoum e Maïmouna Coulibaly, fundadores da Association Arts et Médias d'Afrique, que organiza o festival anual Fest'Africa. A ação consistiu em oficinas com dez escritores do continente e tinha como objetivos (incluindo o Fest'Africa) quebrar o silêncio dos intelectuais africanos durante o genocídio; romper o monopólio do discurso da mídia ocidental e negar a falsa interpretação daquele fato como "massacres interétnicos" provocados por um ódio secular; sair do silêncio para combater o negacionismo e começar um trabalho de memória (NGOM, 2013). Se, por um lado, como argumenta Issa Ngom, a operação recebeu apoio e contou com a colaboração de vários pensadores e escritores africanos que introduziram no cenário da África 
francófona o tema do genocídio tutsi, por outro, foi fortemente criticada por vários motivos.

Dentre os escritores envolvidos no projeto, apenas dois eram ruandeses e estes não estavam presentes durante o genocídio. Os demais entraram no país como estrangeiros e, à maneira de Philip Gourevitch, ${ }^{2}$ coletaram informações que deram origem a narrativas questionáveis, como expõe Akemi Aoki, no artigo intitulado "L'ainé des orphelins na Operação Ruanda: escrever por dever de qual memória?":

na agenda dos escritores, havia encontros com membros de ONGs, sobreviventes, prisioneiros, jornalistas e escritores baseados no país, além de visitas a memoriais do genocídio, lugares de memória que se tornaram parte da indústria do dark tourism de Ruanda. Todos os textos resultantes do projeto - quatro romances, dois livros de viagem, dois ensaios e uma coleção de poemas comentam esses lugares. (AOKI, 2016, p. 6043-6044)

Nenhum dos envolvidos nas oficinas de escrita, cujas obras vieram a público em 2000, durante o Fest'Africa, poderia falar, portanto, como testemunha direta, uma vez que eram, em certa medida, viajantes atraídos pelo acontecimento e motivados por um engajamento político, à procura de episódios a serem escritos - como se os sobreviventes estivessem em prateleiras de personagens disponíveis para consultas de escritores envolvidos em tal tarefa. ${ }^{3}$ Lidar com a memória de vítimas e

${ }^{2} \mathrm{O}$ jornalista norte-americano publicou (após três anos ouvindo sobreviventes, assassinos e cúmplices do genocídio de Ruanda) Gostaríamos de informá-lo de que amanhã seremos mortos com nossas famílias, uma das obras mais conhecidas no ocidente sobre a catástrofe.

${ }^{3}$ Akemi Aoki (2016, p. 6043), ao comentar sobre o mal-estar gerado nos sobreviventes e em alguns escritores que se debruçaram sobre o genocídio de Ruanda, assim expõe: "Véronique Tadjo, em L'ombre d'Imana: voyages jusqu'au bout du Rwanda (2000), comenta sua posição ambígua de turista/viajante na tarefa de escrever sobre o genocídio e se pergunta: 'Como falar do genocídio se eu não estava lá?' [...]. Boubacar Boris Diop conta que alguns ruandeses lhe diziam: 'Cuidado, não somos personagens, não escrevam com os nossos sofrimentos' (BIOP apud MONCEL, 2000, tradução nossa). No documentário Nós não estamos mais mortos, de François Woukoache (2000), uma jovem pergunta aos escritores: "Quando o genocídio estava se preparando, por que vocês e outros escritores não escreveram? Eu teria preferido que vocês tivessem feito prova dessa solidariedade antes que tivesse acontecido o irreparável”. 
sobreviventes exige, por parte de escritores, um compromisso ético com o ato de narrar, sobretudo quando muitos dos assassinos ainda estão vivos e em liberdade e quando muitas das pessoas envolvidas não têm acesso às formas escritas ou estão em um contexto no qual a cultura do livro é quase inexistente.

Catherine Mazauric (2002), professora de Literatura Contemporânea de Expressão Francesa na Universidade de Aix-Marselha, analisando os resultados da "Operação Rwanda", busca refletir sobre o que trazem textos literários - obras poéticas e especialmente ficcionais - que não trariam as análises de historiadores, filósofos ou cientistas políticos. $\mathrm{O}$ questionamento é central quando se trata de narrativas acerca de eventos traumáticos. Em primeiro momento, é preciso admitir que essas manifestações não vinculam sua tarefa fulcral às concepções de ordem estética. Há um chamado à política da memória e da dor, como se o escritor estivesse comprometido com a tarefa de conservar um "patrimônio negativo" - como se refere o sobrevivente Jean Améry (2013) ao dar testemunho da experiência traumática que viveu durante a Shoah - ou um "patrimônio simbólico" - como argumenta Hèléne Piralian (2000) ao tratar do genocídio armênio. Segundo essa psicanalista, escrever, nas circunstâncias de um pós-genocídio, converte-se "então em uma tentativa de inscrever na textura mesma dos textos aquilo que os genocidas trataram de excluir do campo dos herdeiros" (PIRALIAN, 2000, p. 21, tradução nossa). ${ }^{4}$ Em outras palavras, se o projeto genocida tem a clara intenção de eliminar, apagar; a escrita pode se revelar, enquanto pharmakon, como espaço simbólico que marca, registra e ajuda a lembrar. Narrar, no pós-genocídio, tem, portanto, a potência de um ato de resistência, de dar testamento aos mortos; é, com palavras, dar aos silenciados e desaparecidos uma existência pós-eliminação. A tarefa faz dialogar passado e futuro: ao evitar esquecer, compromete-se na tentativa de evitar que as catástrofes sejam reproduzidas.

Ainda sobre o questionamento feito por Mazauric (2002) - ou seja, em que a narrativa de teor testemunhal seria diferente do relato historiográfico? -, pode-se dizer que a primeira diferença reside no fato de que aquela se coloca em função da memória e da dor da vítima e do sobrevivente, enquanto este se coloca em função dos fatos. No

\footnotetext{
${ }^{4}$ No original: “[...] entonces em uma tentativa de reinscribir en la textura mismo de los textos aquello que los genocidas trataron de excluir del campo de los herederos".
} 
desdobramento dessa questão, talvez possamos recorrer a uma expressão cunhada por Rithy Panh (L'IMAGE..., 2013), sobrevivente do genocídio cambojano: "l'image manquante" ("A imagem perdida"). Para o cineasta, a história produziu muitas imagens, mas nenhuma se aproxima da experiência de trabalho forçado, de fome e de perda de seus familiares. Para ele, o cinema aparece como linguagem que abre a possibilidade para falar do trauma e dos anos de horror e questionar os arquivos incapazes de reproduzir o evento traumático. Todavia, nenhuma forma, nenhum gênero de ficção ou não ficção seria capaz de dar conta do evento, da experiência em si. Como aponta Márcio Seligmann-Silva (2003, p. 46), o testemunho coloca-se desde o início, sob o signo da sua simultânea necessidade e impossibilidade: "de um lado, a percepção tanto da insuficiência da linguagem diante dos fatos (inenarráveis) como também [...] a percepção do caráter inimaginável dos mesmos e da sua consequente inverosimilhança". Há uma cisão entre a linguagem, que cria a possibilidade do testemunho, e o evento. "Essa linguagem entravada [...] só pode enfrentar o "real" equipada com a própria imaginação: por assim dizer, só com a arte a intraduzibilidade pode ser desafiada - mas nunca totalmente submetida" (SELIGMANN-SILVA, 2003, p. 47). Resta ao escritor, aquele que atravessou a morte, portanto, recorrer à imaginação para dar conta de elaborar a experiência do horror.

É nesse sentido que podemos pensar a narrativa de Scholastique Mukasonga. À maneira de Rithy Panh em relação à linguagem cinematográfica, a autora também parece ter encontrado no ato de narrar um mecanismo para erguer um patrimônio simbólico aos seus 37 familiares assassinados durante a perseguição aos tutsis. Nascida em 1956, a ruandesa, com sua família e a de tantos outros tutsis, é desterrada em 1960 para a região pantanosa e insalubre de Nyamata, em Bugesera. Em 1973, ela é expulsa da Escola de Assistência Social de Butare e tem de se exilar no Burundi, um ano após o conflito ocorrido nesse país, que resultou na morte de mais de dois mil tutsis, que controlavam o poder, e de mais de cem mil hutus. No ano do genocídio de Ruanda, Mukasonga estava na França, onde residia desde 1992, após casar-se com um francês.

A obra da ruandesa em diáspora, composta por sete livros, todos publicados na França pela editora Gallimard, tem a particularidade de se debruçar, quase sempre, não sobre o genocídio em si (embora sua narrativa tenha como foco nodal esse evento), mas sobre o período anterior e posterior a 1994. Viviane Azarian (2015), professora de Literatura e 
Estudos Comparados na Universidade de Bayreuth, argumenta que a posição particular da autora em relação ao genocídio não é de testemunha direta nem somente de testemunha dos rastros, mas de testemunha vítima, o que determina uma postura enunciativa paratópica. As estratégias de seu discurso são baseadas em uma postura enunciativa de dentro, enquanto uma tensão é estabelecida entre o interior e o exterior, em relação à distância da alteridade da experiência, ao espaço dos acontecimentos e à passagem do tempo. Tal posição parece evidente quando do lançamento de sua primeira obra, em 2006, com o título Inyenzi ou les Cafards, ${ }^{5}$ uma narrativa autobiográfica sobre a qual a autora comenta: "Eu não estava entre os meus quando os esquartejaram com um facão. Como eu poderia continuar a viver durante os dias da morte deles? Sobreviver! É, em verdade, a missão que nossos pais haviam confiado a André e a mim" (MUKASONGA apud BRODZIAK, 2016, ${ }^{6}$ tradução nossa). ${ }^{7}$

Outro aspecto sobre a produção de Mukasonga apontado por Azarian (2015) diz respeito às relações entre gênero literário e testemunho. Conforme autora, a poética do testemunho, na escala de todo o trabalho de Mukasonga, é distribuída cruzando diferentes gêneros ou diferentes configurações testemunhais, com uma escrita híbrida, que borra fronteiras entre referencialidade e ficção. Em 2008 vem a público o relato biográfico La Femme aux pieds nus, que recebeu o prêmio Seligmann contra o racismo e foi traduzida e publicada no Brasil em 2017, pela editora Nós, com o título A mulher de pés descalços. O relato é composto como uma espécie de mortalha, de narrativa-luto, reivindicação de ritual funerário - impossibilitado pelo genocídio - no qual a mãe é a primeira que cobre o filho e o filho é o último que cobre a mãe, como se expõe logo nas primeiras páginas da narração:

Não cobri o corpo da minha mãe com o seu pano. Não havia ninguém lá para cobri-lo. Os assassinos puderam ficar um bom tempo diante do cadáver mutilado por facões. As hienas e os cachorros, embriagados de sangue humano, alimentaram-se

\footnotetext{
${ }^{5}$ Publicada no Brasil pela editora Nós, em 2018, com o título Baratas.

${ }^{6}$ Disponível em: <https://diacritik.com/2016/12/22/memorial-romanesque-pour-ungenocide-scholastique-mukasonga-par-sylvie-brodziakmemorial-romanesque-pourun-genocide-loeuvre-de-scholastique-mukasonga/>

${ }^{7}$ No original:"Je n'étais pas parmi les miens quand on les découpait à la machette. Comment ai-je pu continuer à vivre pendant les jours de leur mort? Survivre! C'était, il est vrai, la mission que nous avaient confiée les parents à André et à moi”.
} 
com a carne dela. Os pobres restos de minha mãe se perderam na pestilência da vala comum do genocídio, e talvez hoje, mas isso não saberia dizer, eles sejam, na confusão de um ossuário, apenas osso sobre osso e crânio sobre crânio.

Mãezinha, eu não estava lá para cobrir o seu corpo, e tenho apenas palavras - palavras de uma língua que você não entendia - para realizar aquilo que você me pediu. E estou sozinha com minhas pobres palavras e com minhas frases, na página do caderno, tecendo e retecendo a mortalha do seu corpo ausente (MUKASONGA, 2017, p. 6-7).

Se a narradora abre o livro com um epitáfio, dedica-se, nas demais páginas, a singularizar e subjetivar não a morte, mas a vida de sua mãe, retirando-a do monte de ossos que apaga sua face, sua carne devorada por animais, sua existência. Corpo prenhe de corpos desaparecidos (PIRALIAN, 2000), Mukasonga reconstitui lugares coletivos, familiares e individuais pela literatura. Como ela, o leitor não saberá sobre o momento exato da morte de Stefania nem como isso ocorreu. Enquanto no primeiro capítulo e em alguns outros momentos se conhece as circunstâncias do desterro, da perseguição e violência dos soldados hutus, do trabalho forçado e as estratégias maternas de vigilância e proteção aos filhos, passasse-se, em seguida, a um processo narrativo de conservação da memória da família e da cultura tutsi. Em resumo: uma etnografia enlaçada em memória afetiva. Recuperam-se as narrativas orais, vocábulos do kinyarwanda, a construção e organização interna da casa (inzu), a cultura e a festa do sorgo (umuganura), a medicina tradicional e a cura pela palavra, os rituais de apresentação dos bebês (Ubunyano) e de casamento. Em um jogo dialético entre desaparecimento e conservação dos traços, Mukasonga insere uma dupla memória em sua obra: o desejo de preservar os traços do passado e a manutenção da promessa implícita de ser guardiã da memória da família, da memória de sua mãe (AZARIAN, 2015).

Tal perspectiva, isto é, a luta contra o desaparecimento e a tarefa de guardar as memórias, prolonga-se em seu primeiro romance, que se pode considerar como um prelúdio ao genocídio: trata-se de Nossa Senhora do Nilo, também lançado no Brasil em 2017 pela editora Nós. Nele, a narradora compartilha com outras vozes a denúncia da situação das meninas e mulheres, mas também a tentativa de apagamento dos tutsis na Ruanda independente. O microcosmo de observação dessa sociedade ruandesa é um colégio católico, cujo nome dá título ao livro, situado no 
alto de uma colina, próximo à nascente do rio Nilo, e onde se cruzam política, religião, colonialismo, machismo e violência, sob o manto de um discurso de avanço, progresso e de modernidade.

Nos capítulos iniciais, a narradora, em tom irônico, apresenta a origem do epíteto do liceu, o perfil das estudantes e retoma a história de construção do espaço voltado para a educação das mulheres da nova sociedade ruandesa. Nesse ponto da narrativa ocorre uma passagem sobre a qual gostaríamos de nos deter:

Durante muito tempo as fotos da cerimônia da inauguração da estátua de Nossa Senhora do Nilo enfeitaram o longo corredor que servia de sala de espera aos pais das alunas que iam se reunir com a madre superiora. Agora, só resta uma foto, na qual se vê o monsenhor vigário apostólico abençoando a estátua. Das outras, sobraram apenas as marcas retangulares. Um pouco mais pálidas que o resto da parede, deixadas atrás do sofá de madeira duro [...] (MUKASONGA, 2017, p. 11).

No fragmento, enunciam-se os fatos e os processos de mudança cujas marcas se inscrevem nas paredes do corredor do liceu. A fotografia capta e congela um tempo-espaço que vai desaparecer ou já desapareceu, como bem analisa Philippe Dubois em $O$ ato fotográfico (1993). No romance de Mukasonga, as próprias fotografias desaparecem das paredes atrás do sofá, restando uma inscrição retangular sobre a tinta esmaecida. As marcas são índices de que algo mais aconteceu, para além do enquadramento da fotografia ainda em exposição. Logo o leitor fica sabendo que as imagens não foram destruídas, apenas deixaram de estar à vista. Três personagens - Gloriosa, da etnia hutu; Modesta, filha de pai hutu e de mãe tutsi; e Veronica, tutsi - vão, por acaso, "des-cobrir" as imagens no arquivo da biblioteca.

Esta passagem é iluminadora de todo o procedimento narrativo empreendido pela escritora ruandesa: o uso das palavras "resta", "sobraram" e "arquivos" (MUKASONGA, 2017, p. 11), ao lado do fato de que são três meninas de diferentes condições étnicas que acham as fotografias, aponta para um processo mais amplo, ou seja, uma metáfora da relação entre arquivo e memória, aparecimento e desaparecimento não só no enredo do romance, mas também na história de Ruanda. Aquilo que está exposto na parede não é o todo, mas apenas um recorte, um fragmento que aponta para o arquivo. Este, por sua vez, aponta para o evento, que será contado, via literatura, pelas vozes de meninas usadas 
como moedas de troca dos interesses masculinos, meninas historicamente silenciadas, obrigadas, na escola, a falar o francês e o inglês (língua não utilizada em suas comunidades) e proibidas de falar o kinyarwanda.

As fotografias, desarquivadas pelas personagens, não falam por si só nem restituem o já abolido, apenas atestam que algo existiu e esteve diante da câmera. Todo o processo só se torna possível porque alguém primeiramente encontra as imagens arquivadas e, em seguida, uma voz narrativa, atuando como punctum, as situa, revelando o que está para além do enquadramento, descongelando os fatos, colocando-os em açãouma ação narrativa que se torna possível pelo trabalho de rememoração. Quando as alunas mexem na biblioteca e ao acaso encontram o arquivo, revelam-se, então, outras imagens, feitas de palavras, acerca de um evento situado num tempo-espaço de outrora, mas que vai ressoar por mais de três décadas até os cem dias de carnificina humana:

Numa foto, via-se o administrador fazendo um cumprimento militar diante da estátua enquanto, atrás dele, um soldado inclinava a bandeira belga. Em outra, estavam os dançarinos intores um pouco desfocados, pois o fotógrafo, inábil, quisera captar o salto prodigioso em pleno voo e, assim, a crina de sisal e a pele de leopardo ficaram envoltas por uma auréola fantasmagórica. Além disso, havia uma foto dos chefes e suas esposas, vestidos com grande pompa. Quase todos esses personagens importantes estavam riscados com caneta vermelha, e alguns outros tinham por cima um ponto de interrogação feito com caneta preta. [...] Veronica ficou se perguntando quando seria a vez dela ser riscada com caneta vermelha na foto de turma que tiravam todos os anos no início das aulas (MUKASONGA, 2017, p. 12).

As fotografias funcionam como mote. A partir delas resgata-se, pela palavra e pela própria imagem fotográfica, a presença massacrante e operadora de um extermínio cultural, político, econômico e étnico iniciado nos anos de colonização europeia e ainda em prática no período póscolonização. Em oposição ao arquivamento e aos processos destrutivos operados em Ruanda, resta trazer à vista as imagens silenciadas, fantasmagóricas de moradores e da cultura local. Jovens intores, dançarinos de rituais sagrados, desfocados pela tentativa do fotógrafo de captar o movimento (sabemos que a fotografia é contrária ao movimento, ela o congela) e as personagens riscadas de caneta vermelha são "desarquivizadas" (SELIGMANN-SILVA, 2014) via ficção, via memória. 
A caneta vermelha que risca a imagem fotográfica será a machete que vai riscar de Ruanda a vida de tantos tutsis. O medo de Veronica de ser a próxima na lista de riscados ecoará da década de 1970 (tempo da narrativa) até 1994 sem que o mundo ouça o grito de socorro das vítimas. Mas será também uma caneta que irá, no tempo pós-genocídio, inscrever a memória das vítimas e sobreviventes. Esse processo de "anarquivamento" do arquivo, realizado por Mukasonga, reembaralha os arquivos e recoleciona suas ruínas, reconstruindo-as de forma crítica (SELIGMANN-SILVA, 2014). Como as fotografias encontradas no arquivo, a caneta é uma forma de trazer à vista o que está oculto, de colocar em aparência aquilo que está em vias de desaparecimento. Esse aparecimento ocorre não como uma imagem do real e inteira, mas como um resto, como argumenta Carlo Ginzburg ao pensar o campo da Historiografia (2007): uma vez que não se pode ter acesso ao acontecimento, é preciso trabalhar com o rastro, construindo a narrativa com os fios que restaram.

Nesse rastro de inscrição a contrapelo da história, da geografia e da cultura ruandesa a partir da perspectiva de uma escritora tutsi, é que Mukasonga retoma, via romance e com uma linguagem marcada pela ironia e pelo sarcasmo, a memória dos ancestrais e do sobrenatural solapada durante os anos de colonização e que continuou nos anos de independência pela ação da igreja católica no projeto educacional do país. São as personagens da etnia tutsi, Veronica e Virginia, estudantes que fazem uso dos $10 \%$ da cota tutsi no liceu, que conduzem o leitor ao universo da cultura local. Virginia, ao longo do romance, oferece às colegas e ao leitor as tradições camponesas, o modo de preparar as refeições, o acontecimento da menarca na vida de uma tutsi da aldeia, a passagem da infância para a vida adulta, o tornar-se mulher.

Veronica, em um dos episódios, visita, juntamente com Imaculée, o curandeiro Kagabo, que as leva até Nyamirongi, a fazedora de chuva que, ao assumir a voz na narrativa, retoma as tradições no período anterior ao catolicismo e ao colonialismo. Enquanto Imaculée (hutu) deseja que se realize um feitiço para conquistar o namorado, Veronica procura saber os mistérios para fazer chover e fazer parar de chover.

Adiante, as duas estudantes tutsis acabam se envolvendo com outra personagem: Fontenaille, um pintor europeu, dono de propriedades na região próxima ao Nossa Senhora do Nilo. Este constrói em suas terras um templo em cujas paredes estão pintadas imagens de intores, vacas, 
reis e rainhas. O objetivo do europeu é revelar e recuperar a memória ancestral, segundo ele, esquecida pelos tutsis. Todavia, sua arrogância ocidental acaba alterando as ruínas arqueológicas presentes em suas propriedades e, por consequência, a ordem sobrenatural.

A Virginia é dada a tarefa de pôr em ordem aquilo que Fontenaille desestrutura. Desde a visita ao templo, ela passa a ter sonhos recorrentes com uma rainha. Buscando entender e libertar-se da situação, a aluna vai até a cabana de Rubanga, um umwiru, isto é, um guardador de segredos (ibangas) dos reis (abirus). O diálogo entre o ancião e a estudante passa pela reflexão sobre o processo de colonização e as consequências desastrosas para a memória. Apesar das perseguições de padres e colonos, sofridas por Rubanga, ele não esquece os segredos a ele confiados. Nem poderia, pois para "um umwiru o esquecimento é a morte" (MUKASONGA, 2017, p. 155), como o foi o registro dos segredos feito pelos brancos em livro. Ao final da conversa, ele afiança a Virginia: "Foi isso que eu vi, é tudo que eu sei, é o que tenho para contar" (MUKASONGA, 2017, p. 160). A menina recebe, então, os segredos, tornando-se uma umwiru. Recebe também a tarefa de enterrar novamente os restos mortais dos túmulos profanados pelo europeu.

Nas páginas finais do romance, Nyamirongi volta a aparecer e, ao abrigar Virginia em sua casa durante a perseguição aos tutsis, revela:

-A chuva me diz que ela vai embora, que vai deixar esse lugar, abrir espaço para a estação da poeira. E ela disse que aqui embaixo, em Ruanda, a estação dos homens mudou. Mas ela me disse ainda para não acreditar nisso: os que acreditarem na calmaria serão surpreendidos por um raio. Serão pegos e vão perecer. Em breve você vai embora (MUKASONGA, 2017, p. 250).

Espécie de alter ego de Mukasonga, Virginia será a única sobrevivente dos ataques hutus contra tutsis em 1973. A revelação da fazedora de chuvas sinaliza a saída da personagem do país e situa outros aspectos do romance sobre os quais gostaríamos ainda de nos debruçar.

\section{Rumor e teor testemunhal: da história para as páginas literárias}

Em $A$ mulher de pés descalços, há um capítulo intitulado "O país das histórias". Nesse, a narradora retoma a cultura oral do país, em uma rememoração das cantigas melancólicas de pastores e das histórias contadas por Stefania ao redor das chamas que cozinham a escassa 
refeição da noite em exílio. Entremeando esse país de narrativas de pastores entoadas e contadas pelos mais velhos, Mukasonga introduz outro tema recorrente na história de Ruanda, plantado nos tempos da colonização: a invenção da hipótese hamítica e do rumor como estratégias de poder. Ambos terão um papel fundamental no estabelecimento de eventos que vão culminar no genocídio. Assim expõe a narradora:

Há outras histórias também. Histórias que não eram nossas, que não eram contadas em volta do fogo. Histórias que são como porções preparadas pelos envenenadores, histórias cheias de ódio, de morte. Histórias contadas pelos brancos. [...]

Os brancos pretendiam saber melhor do que nós quem éramos e de onde vínhamos. Eles nos apalparam, nos pesaram, nos mediram. As conclusões a que chegaram foram categóricas: nossos crânios eram caucasianos, nossos perfis, semíticos, nossa estatura, nilótica. Eles conheciam até mesmo nosso ancestral [...]. Os cientistas (a quem devíamos ser gratos) tinham feito até uma raça sob medida para nós: nós éramos os Camitas! [...]

Não sei como esse rumor maligno chegou até a minha mãe. Como todos os ruandeses ela sabia [...] (MUKASONGA, 2017, p. 121-122).

O fragmento é parte do processo de revisão e contestação dos discursos colonialistas empreendido por Mukasonga em sua obra. Como afirma Seligmann-Silva (2014, p. 39) ao estudar os processos e as estratégias de "anarquivamento" realizados no campo das artes, sobretudo depois da Segunda Guerra Mundial, o "artista quer destruir [...] arquivos que funcionam como máquinas identitárias de destruição (pois eliminam os que são diferentes do "tipo")". Dentre os arquivos que a escritora ruandesa busca desconstruir estão a invenção da hipótese de origem hamítica dos tutsis; e a reforma belga do estado colonial em meados da década de 1920 até meados da década de 1930 que constituiu Hutu como indígena Bantu e Tutsi como camitas estrangeiros (MAMDANI, 2002). Tais ações, discursivas e práticas, atravessaram o século XX. Na década de 1990, os rumores sobre a "ameaça tutsi" culminaram em propagandas divulgadas em jornais e em canais de TV de Ruanda e a carteira de identidade étnica foi um dos elementos usados para definir quem deveria morrer.

Em Nossa Senhora do Nilo (2017), o rumor surge de forma discreta e vai ganhando proporções à medida que a narrativa avança. A 
primeira vez que aparece o discurso sobre as cotas para tutsis e a ameaça que a etnia representa aos hutus ocorre nas páginas iniciais do romance, quando Gloriosa, aluna hutu, questiona a quantidade de meninas tutsis no colégio e defende que algo precisa ser feito para "acabar com os parasitas" (MUKASONGA, 2017, p. 32). O comentário, aparentemente passageiro, ocorre em meio à chegada de várias alunas de famílias abastadas de Ruanda. Ainda no mesmo capítulo, intitulado "Volta às aulas", padre Herménégilde faz um discurso nacionalista no qual relembra o "Manifesto Hutu", de 1957, localiza os hutus como raça majoritária, a única autóctone, e destaca que "o povo da enxada, desbravador das imensas florestas de Ruanda até então impenetráveis, tinha, finalmente, se libertado dos novecentos anos de dominação camita" (MUKASONGA, 2017, p. 37). Aí se vê que não há acusação alguma ao poder colonial belga. Muito pelo contrário: ao longo do romance, revela-se que a relação entre Ruanda independente e Bélgica permanece em um diálogo servil, em que o próprio presidente do país decide doar Merciana, uma de suas filhas, ao rei e à rainha belgas como forma de resolver a esterilidade do casal e de estreitar os laços entre as duas nações.

É ainda o padre Herménégilde, nacionalista, patriota, abusador sexual das meninas do liceu, quem, inspirado n'Os Protocolos dos sábios de Sião - texto antissemita do final do século XIX - vai narrar à Madre Superiora rumores sobre planos de dominação e de estabelecimento de um império tramados por tutsis:

Quando estava no seminário, li um livro [...] secreto escrito pelos próprios judeus, não sei quem foi que o revelou. Os judeus escreveram que desejavam conquistar o mundo, que tinham um governo secreto que manipulava todos os outros governos, que se infiltrava por todo o canto. Bom, o que eu tenho a dizer é que os tutsis são como os judeus, que está na Bíblia. Talvez eles não queiram conquistar o mundo, mas querem se apossar de toda a região. Sei que eles têm o projeto de um grande império camita, seus chefes se reúnem em segredo, como os judeus [...] (MUKASONGA, 2017, p. 126)

Em função da "ameaça" sustentada via rumor, o padre segue expondo e justificando a necessidade de eliminar, a exemplo do que ocorreu com os judeus, os "parasitas" tutsis, não só de Ruanda, mas de todas as regiões vizinhas. Além dele, outras personagens de origem europeia vão sustentar os rumores e ideologias oriundas do processo 
de colonização. Fontenaille é um dos que resgata a hipótese da origem estrangeira dos tutsis. Ao viajar até o Sudão e o Egito e, posteriormente, ilustrar as paredes do templo que constrói com imagens de Isis (deusa egípcia da maternidade e da magia) e de Candace (rainha da Etiópia), vai associá-las às personagens Veronica e Virginia e defender que a origem dos tutsis está no Império dos faraós negros.

Padre Pintard, como o colega, recorre à bíblia para explicar à Virginia sua origem étnica. Mas vai mais longe e resgata, a partir da narrativa judaico-cristã de peregrinação à terra prometida, a história da soberania tutsi e a inversão do jogo. Conforme o religioso, quando Moisés abriu o mar Vermelho, alguns erraram o caminho e rumaram para o sul, chegando ao país de Koush - esses seriam os primeiros tutsis. A rainha de Sabá, que também seria tutsi, visita o rei Salomão e volta com um filho, que seria imperador de um país onde os judeus eram tutsis chamados Falashas (MUKASONGA, 2017). Por fim, como se estivesse em uma homilia, o sacerdote aconselha Virginia a aceitar como determinação divina o destino trágico do seu povo.

Dentre as alunas, é Gloriosa quem mais demonstra paixão pelas teorias raciais e quem dá vazão aos rumores. Como já foi apontado, desde as primeiras páginas do romance o discurso de ódio se faz presente e ganha maior proporção à medida que a narrativa avança. As ideias da estudante são de ataque e de exclusão aos tutsis em oposição ao pertencimento natural dos hutus. Peter Geschiere, em The Perils of Belonging (2009), situa a invenção da autoctonia como uma forma básica de pertencimento e de direito à cidadania. Tal forma atua, por outro lado, como requisito de exclusão daqueles tidos como estrangeiros ou recémchegados, criando-se, assim, a categoria de não cidadãos, daqueles que não devem e não podem ser partícipes nas políticas públicas e nos direitos dos verdadeiros cidadãos. Por essa ótica, isto é, hutus como verdadeiros autóctones, e tutsis como estrangeiros sem direito à cidadania, torna-se possível, e até necessário, eliminá-los.

Mukasonga, contestando discursos sobre autoctonia e identidade como vistos pela perspectiva ocidental, introduz, no capítulo que se intitula "O sangue da vergonha", o tema tabu da menstruação, mas também uma discussão sobre o sangue tutsi que a personagem Modesta carrega. O acontecimento da menarca e os pesadelos da menina-mulher com o sangue que escorre em sua perna e mancha o nobre vestido azul, aparecem como mote para outra questão mais profunda. Modesta é hutu porque seu pai 
também o é, mas é filha de mãe tutsi. Tais condições fazem pairar, sobre todos os membros da família, constantes desconfianças, principalmente em relação à mãe, que é odiada, inclusive pelos filhos. Há na exposição desse caso a problematização das ideias polarizadas de identidade étnica. O pai de Modesta, desejando identificar-se como tutsi, casa-se com uma mulher dessa etnia, mas depois volta a identificar-se como hutu.

Mahmood Mamdani, em When Victims Become Killers (2002), livro fundamental para a compreensão dos processos políticos, geográficos e históricos que desaguaram no genocídio de 1994, identifica dois tipos de identidades: política e cultural. Enquanto a primeira é fixa e inscrita em leis criadas pelo Estado; a segunda é ambígua, não fixa e implica o compartilhamento de um passado, de uma herança histórica comum. Como consequência, o direito civil colonial, em vez de uma cidadania universal, deu origem a diferentes categorias de cidadãos: cidadãos de fato, cidadãos virtuais e não cidadãos. Um dos fracassos da Revolução de 1959, da Primeira (1962-1973) e da Segunda (19731994) República em Ruanda decorre da incapacidade de transformar esse quadro. Em um contexto mais amplo, o cerne da crise da cidadania na África pós-colonial, conforme discorre o teórico, reside no fracasso em transcender as identidades políticas de nativo e colonizador criadas pelo colonialismo moderno.

Herdeira dessas concepções ideológicas oriundas da colonização, Gloriosa assume o protagonismo no capítulo que se intitula "O nariz da virgem". A personagem expõe à Modesta o plano para apagar na estátua de Nossa Senhora do Nilo os vestígios que representam os tutsis. O apagamento do nariz, o traço tutsi na imagem, é parte do plano, ensinado à Gloriosa pelo próprio pai, para "des-tutsizar” (MUKASONGA, 2017, p. 209) Ruanda. Modesta, ao ouvir as ideias da melhor amiga, prefere achar que não passam de piadas bizarras. Todavia, o plano se concretiza e, para situar o gesto como ato político, as duas meninas concordam em sustentar a narrativa de que foram atacadas e quase violentadas por inyenzis. Gloriosa assim justifica sua atitude: "-Meu pai sempre diz que a gente precisa repetir sem parar que ainda existem inyenzis, que eles estão sempre prontos para voltar, que se infiltram entre a gente, que os tutsis que sobraram esperam impacientes" (MUKASONGA, 2017, p. 215). A menina será capaz de sustentar o falso testemunho por quatro vezes, acrescentando sempre mais detalhes em cada versão. Na primeira, afirma que foram atacadas por homens tutsis com rostos cobertos, que queriam 
estuprá-las e matá-las. Nas versões seguintes, aumenta significativamente a violência e o número de tutsis que almejam estuprar, torturar e matar todas as alunas e religiosas do liceu. Na quarta versão, Gloriosa afirma ter reconhecido a voz de um dos agressores, que seria Jean Bizimana.

$O$ relato mobiliza governo e militares em uma caça aos supostos criminosos. A operação termina com a prisão e tortura de uma vítima, a única nomeada pela estudante hutu. $\mathrm{O}$ fragmento, como todo o romance de Mukasonga, é importante para pensar, via literatura, como a população construiu o retrato do bode expiatório. O falso testemunho de Gloriosa é palavra que mata, como também o é o processo de desumanização construído histórica e discursivamente, alastrando-se, via rumor, até a eliminação das vítimas, nomeadas pejorativamente inyenzis, baratas, parasitas.

O horror do colonialismo, como argumenta Mamdani (2002, p. 9-10), levou a dois tipos de impulsos genocidas: o primeiro foi o genocídio do nativo pelo colonizador e o segundo, o impulso nativo de eliminar o colono. Em ambos os casos, ainda de acordo com o autor, o genocídio ocorre em função não de uma limpeza étnica, mas de uma limpeza racial. Para os hutus, que mataram, os tutsis eram estrangeiros e não vizinhos. Por cumprir essa tarefa de limpeza, Gloriosa é recompensada e tratada como heroína no liceu.

Jean Bizimana é a primeira dentre outras vítimas que viriam. Os rumores e os planos de limpeza são transformados em fatos e avançam sobre a vida das meninas tutsis do colégio. Quando a Juventude Militante Ruandesa (JMR) invade o liceu, Virginia e Veronica, que testemunharam o exílio e a morte de familiares nas perseguições de 1959 e 1963, já a esperavam. A primeira foge e tenta se abrigar no templo de Fontenaille e a segunda, com a cumplicidade de Imaculée, esconde-se no quarto da aluna hutu. É com a ajuda dela e de Kagabo que Virginia chega à casa de Nyamirongi, onde fica escondida por alguns dias, até sair do país. $\mathrm{Na}$ estrada, dentro do carro, é a protetora hutu, como testis (aquela que assiste com um terceiro), quem conta a Virginia, superstes (sobrevivente), o desfecho violento da invasão no liceu, a tortura de sua amiga Veronica, o golpe de Estado em que o exército toma o poder.

A revelação de Nyamirongi se cumpre: a chuva, índice de graça e abundância, é substituída. A desconfiança sobre os discursos da Revolução de 1959 e do progresso de uma nação recém-nascida lança seus ecos até a década de 1990, quando então aproximadamente um 
milhão de corpos serão atingidos como um raio. Se julho de 1962 soava como uma mudança de estação entre os homens, os ataques de 1963, que expulsaram do país grande parte da população tutsi e vitimaram entre 10 e 14 mil ruandeses, e o golpe de Estado, em 1973, foram sinais claros de que a estação que se impõe é a da poeira.

Mukasonga, ao erguer uma narrativa com meninas do liceu, constrói uma polifonia que evidencia os problemas etnorraciais entre alunas e a opressão e as forças coercitivas que atuam sobre a vida de meninas e mulheres, hutus e tutsis. Na escola, na igreja, na sociedade, na política, no campo ou na cidade, todas estão submetidas ao jugo. Veronica é abusada pelo padre Herménégilde, Frida é explorada pelo pai, abusada pelo padre e por Balimba, embaixador do Zaire. Por ser mulher e engravidar antes do casamento, procede-se a um apagamento dessa personagem em todos os planos: na família, na escola, na igreja, na política, na sociedade. As estratégias narrativas (como o humor e o sarcasmo) empregadas pela autora são formas de espezinhar rumores e de proceder a uma crítica ao colonialismo, à igreja católica, ao patriarcalismo, aos agentes da violência.

Palavra-testemunho - que anarquiviza a palavra-rumor, o falso testemunho, a palavra que mata, a palavra-grito não ouvida -, a narrativa de Scholastique Mukasonga é o grito contra a cumplicidade de padres e freiras diante da violência praticada no e pelos administradores do liceu. $\mathrm{O}$ grito de socorro de meninas exploradas, abusadas e violentadas sexualmente, perseguidas por sua condição étnica, é o grito ignorado de milhares, ecoando pelo mundo até os cem dias entre o 7 de abril e o 4 de julho de 1994. Palavra negada na História, a narrativa de Mukasonga se inscreve pela palavra que possibilita o trabalho com a memória e o testemunho, dando túmulo e um altar de palavras àqueles que já foram emudecidos pela morte.

No final de $A$ mulher de pés descalços, a narradora vê-se diante da dor e do pesadelo que há tanto tempo ronda suas noites e sobre o qual ela escreve. Em meio a descrições sobre o processo de escrever as memórias da mãe, introduz uma imagem: crianças fardadas saem da escola, formando uma fila comprida e silenciosa que segue pela estrada até o acampamento militar de Gako, na fronteira com o Burundi. A narradora está no meio das meninas e, de repente, também se encontra com colegas de sua época de estudante. Seguem para colher flores, como o padre havia pedido após a missa dominical. As crianças chegam, então, 
ao pé de uma colina coberta de flores brancas: é Rebero, onde tutsis foram assassinados. A narradora grita para avisar às crianças que não se trata de flores, mas de ossos de vítimas do genocídio:

Na igreja, as crianças carregam buquês, montes, braçadas e feixes de galhos brancos. Digo a elas:

- Essas não são as flores que vocês colheram...

- Não, me diz Cândida, mas veja o que deixamos na frente do altar de Jesus, na frente da estátua de Maria.

Ao pé do altar de Jesus, ao pé da estátua de Maria, vejo vários montes de ossadas: esqueletos de homens e mulheres, de crianças de Nyamata espalhados pelo chão da igreja.

- Você reconhece quem são? Pergunta Cândida. Olhe bem, eles estão aqui e eu estou com eles, você reconhece os seus? Reconhece Stefania?

Cândida é apenas uma sombra cada vez mais tênue e a voz é só um eco distante:

- Você tem um pano grande o suficiente para cobrir todos eles... para cobrir todos... todos...? (MUKASONGA, 2017, p. 156)

Eis a Nossa Senhora de volta. Eis os ossos nas colinas, nas igrejas, ossos dos tutsis sem velório, sem enterro, sem epitáfios. Eis a ineficiência da linguagem para cobrir todos os ossos, todos os mortos, todos os desfigurados por uma humanidade desumana. Walter Benjamin (1994, p. 225), nas teses "Sobre o conceito da história", aponta que "nunca houve um monumento da cultura que não fosse também um documento da barbárie". Roney Cytrynowicz (2003, p. 137), afinado com o pensamento do filósofo alemão, conclui: "é preciso que cada documento da barbárie seja recuperado [...], publicado e exposto, de forma a tornar a história uma forma presente de resistência e de registro digno dos mortos". Restam-nos, talvez, as narrativas de sobreviventes como ato de escovar a história a contrapelo, como forma de deter o anjo da história para acordar os mortos e juntar os fragmentos, e impedi-lo de seguir adiante, impelido pela tempestade, pelo progresso que acumula um amontoado de ruínas que cresce até o céu (BENJAMIN, 1994).

Ao professor Márcio Seligmann-Silva, pelas aulas e diálogos que resultaram neste artigo. 


\section{Referências}

AMÉRY, J. Ressentimentos. In: . Além do crime e do castigo. Trad. Marijane Lisboa. Rio de janeiro: Contraponto, 2013. p. 107-132.

AOKI, A. L'ainé des orphelins na operação Ruanda: escrever por dever de qual memória? In: ENCONTRO INTERNACIONAL DAABRALIC, 15., 2016, Rio de Janeiro. Anais eletrônicos... [S.1.]: ABRALIC, 2016. p. 6040-6046. Disponível em $<\mathrm{http}$ ://www.abralic.org.br/anais/ arquivos/2016_1491571843.pdf >. Acesso em: 13 maio 2018.

AZARIAN, V. Poétique du témoignage dans l'œuvre de Scholastique Mukasonga. liRCO, Limoges, 2015. Disponível em: $<\mathrm{https} / / / \mathrm{www}$. unilim.fr/iirco/2015/03/19/viviane-azarian-poetique-du-temoignagedans-loeuvre-de-scholastique-mukasonga/>. Acesso em: 11 abr. 2018.

BENJAMIN, W. Sobre o conceito da História. In: . Magia e técnica, arte e política: ensaios sobre literatura e história da cultura. Trad. Sérgio Paulo Rouanet. 7. ed. São Paulo: Brasiliense, 1994. p. 222-232.

BRODZIAK, S. Mémorial romanesque pour un génocide: Scholastique Mukasonga. Diacritik, L'Hay-Les-Roses, dez. 2016. Disponível em: $<$ https://diacritik.com/2016/12/22/memorial-romanesque-pour-ungenocide-scholastique-mukasonga-par-sylvie-brodziakmemorialromanesque-pour-un-genocide-loeuvre-de-scholastique-mukasonga/ $>$. Acesso em: 12 maio 2018.

CYTRYNOWICZ, R. O silêncio do sobrevivente: diálogo e rupturas entre memória e história do Holocausto. In: SELIGMANN-SILVA, M (Org.). História, memória, literatura: o Testemunho na era das catástrofes. Campinas: Editora da UNICAMP, 2003. p. 123-138.

DUBOIS, P. O ato fotográfico e outros ensaios. Trad. Marina Appenzeller. Campinas, SP: Papirus, 1993.

GESCHIERE, P. The Perils of Belonging: Authoctony, Citzenship, and Exclusion in Africa and Europe. Chicago: University of Chicago Press, 2009. doi: https://doi.org/10.7208/chicago/9780226289663.001.0001

GINZBURG, C. O fio e os rastros: verdadeiro, falso e fictício. Trad. Rosa Freire d'Aguiar e Eduardo Brandão. São Paulo: Companhia das Letras, 2007. 
L'IMAGE manquante. Direção: Rithy Panh. Argumento: Rithy Panh, Christophe Bataille. Produção: Catherine Dussart. Montagem: Rithy Panh, Marie-Christine Rougerie. Lisboa: Leopardo Filmes, 2013. I vídeo (90 min.), son., color., Fr., legend. Disponível em: $<$ https://www.youtube. com/watch?v=0FR6TnyoAO0 $>$. Acesso em: 14 maio 2018.

MAMDANI, M. When Victims Become Killers. Colonialism, Nativism, and the Genocide in Rwanda. Princeton: Princeton University Press, 2002.

MAZAURIC, C. À quoi bon des poètes? L'Opération Rwanda. Écrire par devoir de mémoire. Itrabalho apresentado no Journee d'Etudes Violences, Conflits et Crises en Afrique Subsaharienne, realizado em maio de 2002 na Université Toulouse II Le Mirail, Réseau Afrique (RAF-UTM). Disponível em: <https://www.academia.edu/12572955/ Op\%C3\%A9ration_RWANDA_-_ECRIRE_PAR_DEVOIR_DE_ MEMOIRE $>$. Acesso em: 13 mar. 2018.

MUKASONGA, S. A mulher de pés descalços. Trad. Marília Garcia. São Paulo: Nós, 2017.

MUKASONGA, S. Baratas. Trad. Marília Garcia. São Paulo: Nós, 2018. MUKASONGA, S. Nossa Senhora do Nilo. Trad. Marília Garcia. São Paulo: Nós, 2017.

NGOM, I. Nouveaux paradigmes narratifs dans les récits du génocide rwandais du Fest'Africa. Ethiopiques: Revue Negro-Africaine de Litterature et Philosophie, [S.1.], n. 90, 2013. Disponível em: $<$ http:// ethiopiques.refer.sn/spip.php?article1859>. Acesso em: 12 maio 2018

PIRALIAN, H. Genocidio e transmission. Prólogo de Héctor Schmucler. Buenos Aires: Fondo de Cultura Económica de Argentina, 2000.

SELIGMANN-SILVA, M. Apresentação da questão. In: (Org.). História, memória, literatura: o Testemunho na era das catástrofes. Campinas: Editora da UNICAMP, 2003. p. 45-58.

SELIGMANN-SILVA, M. Sobre o anarquivamento - um encadeamento a partir de Walter Benjamin. Revista Poiésis, Niterói, n. 24, p. 35-58, dez. 2014. Disponível em: <http://www.poiesis.uff.br/p24/pdf/p24-dossie-3marcio-seligmann-silva.pdf $>$. Acesso em: 23 maio 2018.

Recebido em: 12 de julho de 2018. Aprovado em: 23 de outubro de 2018. 